\title{
26. Association of a Viroid-like RNA from Plum Dapple Disease Occurring in Japan
}

\author{
By Teruo Sano,*) Tatsuji Hataya,*) Yasuo TeraI,**) \\ and Eishiro SHIKATA*) \\ (Communicated by Naohide Hiratsuka, M. J. A., March 12, 1986)
}

Introduction. Plum dapple disease is a newly described disease by Terai $(1985)^{3)}$ in Japanese Plum (Prunus salicina Lindley cv. Taiyo) cultivated in Yamanashi Prefecture, Japan. The infected trees produce dapple fruits with faint reddish and chlorotic blotches, but no visible symptom is recognized on the leaves and stems. The disease is transmissible by grafting, however, the causal agent has not yet known.

In this paper, we describe detection and some properties of a viroid-like RNA associated with plum dapple disease.

Materials and methods. Restriction enzyme and DNA polymerase I were purchased from Takara Shuzo Co., Ltd. DNase I was from Cooper Biomedical, Inc. $\alpha{ }^{32} \mathrm{P}-\mathrm{dCTP}(800 \mathrm{Ci} / \mathrm{mmol})$ was from Muromachi Chemical Inc.

Fruits and leaves of plum dapple disease (PDD) affected and of PDD free trees were collected from Yamanashi Prefecture.

Low molecular weight RNAs were extracted from frozen leaves and skins of fruits by using previously described method, $\left.{ }^{6}\right)$ with some modifications. When leaves were homogenized in $1 \mathrm{M} \mathrm{K}_{2} \mathrm{HPO}_{4}$, the extracts became dark brown with high viscosity because of the high concentration of polyphenolic substances in plum leaves, and large quantities of low molecular weight RNAs were precipitated by $2 \mathrm{M} \mathrm{LiCl}$ precipitation together with high molecular weight ribosomal RNAs and contaminated-impurities. To avoid this loss, the low molecular weight RNAs were recovered from the precipitates by another cycles of $2 \mathrm{M} \mathrm{LiCl}$ solubilizations.

Polyacrylamide gel electrophoresis (PAGE) under non-denaturing condition was carried out on a $15 \%$ gel (acrylamide:bis $=30: 0.8$ ) in a buffer containing $40 \mathrm{mM}$ tris, $20 \mathrm{mM}$ sodium acetate and $2 \mathrm{mM}$ EDTA, $\mathrm{pH} 7.2$ (Loening, 1967).1) PAGE under fully denaturing condition was carried out on an $8 \mathrm{M}$ urea $5 \%$ gel (acrylamide $:$ bis $=30: 0.8$ ) in a buffer containing $25 \mathrm{mM}$ tris, $25 \mathrm{mM}$ bolic acid and $0.5 \mathrm{mM}$ EDTA, $\mathrm{pH}$ 8.3. After electrophoresis, gels were stained with ethidium bromide $(1 \mu \mathrm{g} / \mathrm{ml})$ and observed on a trans-illuminator.

Dot blot hybridization was performed according to the method described by Thomas (1980).5) A full length (1 unit) cDNA copy of hop stunt viroid-cucumber isolate (HSV-c) was excised by restriction endonuclease Xho I digestion from recombinant plasmid pCP 316, which containing 2 units copies of HSV-c cDNA. The 1 unit cDNA was labelled with $\alpha$-32P-dCTP by nick-translation, specific activity was $2 \times 10^{\tau} \mathrm{cpm} / \mu \mathrm{g}$ DNA, and used for hybridization probe. Two $\mu \mathrm{g}$ aliquote of the low molecular weight RNAs was spotted onto a nitrocellulose paper (Schleicher and Schuell) and hybridized with ${ }^{32} \mathrm{P}$-labelled cDNA of HSV-c

Department of Botany, Faculty of Agriculture, Hokkaido University, Sapporo

**) Yamanashi Fruit Tree Experiment Station, Yamanashi 405, Japan. 
$\left(5 \times 10^{5} \mathrm{cpm} / \mathrm{ml}\right)$. After washing, paper was dried and exposed to X-ray film at $-70^{\circ} \mathrm{C}$.

Results. Detection of a low molecular weight RNA specific for PDD from diseased plums: Low molecular weight RNAs extracted from fruits and leaves of PDD affected and PDD free plum trees were electrophoresed on a $15 \%$ gel. As shown in Fig. 1, a specific band was detected from PDD affected plums (arrow $\mathrm{v}$ ), which migrated in the same position as that of HSV. No corresponding band could be detected from PDD free plums.

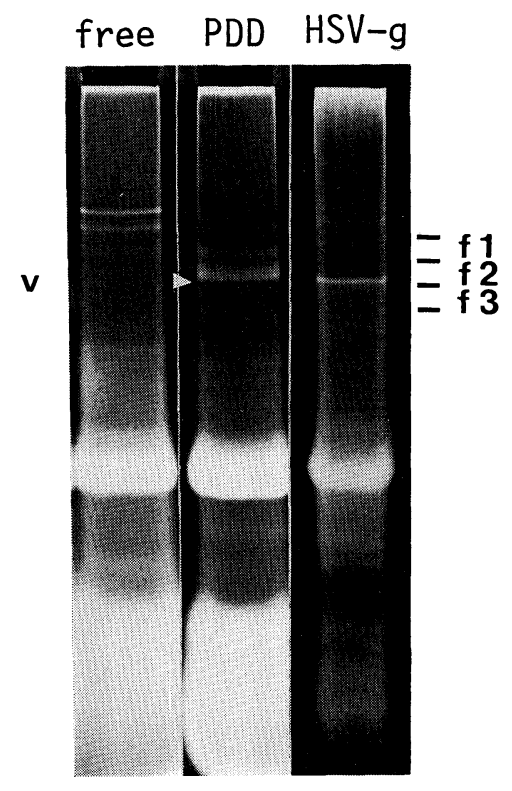

Fig. 1. Electrophoresis on $15 \%$ polyacrylamide gel of low molecular weight RNAs extracted from PDD free plum (free), PDD affected plum (PDD) and HSV-g cucumber (HSV-g). An arrow (v) indicates the PDD specific RNA. Gel fractions of lane (PDD) were excised as indicated in the figure (f1, f2 and $f 3$ ) and the RNAs were electrophoresed in Fig. 2.

Evidence of a viroid-like nature of PDD specific RNA on a PAGE under fully denaturing condition: Ribonucleic acids were eluted from gel slices of a $15 \%$ non-denaturing gel (Fig. 1, f1-f3), by homogenizing in a buffer solution containing $0.5 \mathrm{M}$ ammonium acetate, $0.01 \mathrm{M}$ magnesium acetate and $0.1 \%$ SDS, and were precipitated by ethanol and dried. They were then dissolved in $25 \mu \mathrm{l}$ of electrophoresis buffer containing $0.02 \%$ bromophenol blue, $0.02 \%$ xylene cyanol $\mathrm{FF}$ and $8 \mathrm{M}$ urea, and electrophoresed on a $5 \%$ gel under fully denaturing condition. As shown in Fig. 2, the RNA specific for PDD affected plums (lane f2) migrated more slowly than other RNA species in the gel. The unusual migration nature of this RNA in gels was characteristic for single-stranded circular molecules that are specific for viroid RNAs. Furthermore, the RNA migrated in the same position as that of circular molecules of HSV in fullv denaturing condition, and rather faster than that of circular molecules of potato spindle tuber viroid (PSTV). No such an RNA could be detected from PDD free plum fruits and leaves.

Dot blot hybridization between RNAs from PDD infected plums and cDNA of $H S V-c$ : Low molecular weight RNAs extracted from PDD affected and PDD free plum, HSV-grapevine isolate H(SV-g) infected cucumber and PSTV infected tomato were diluted with distilled water by five-fold dilution. Each was 


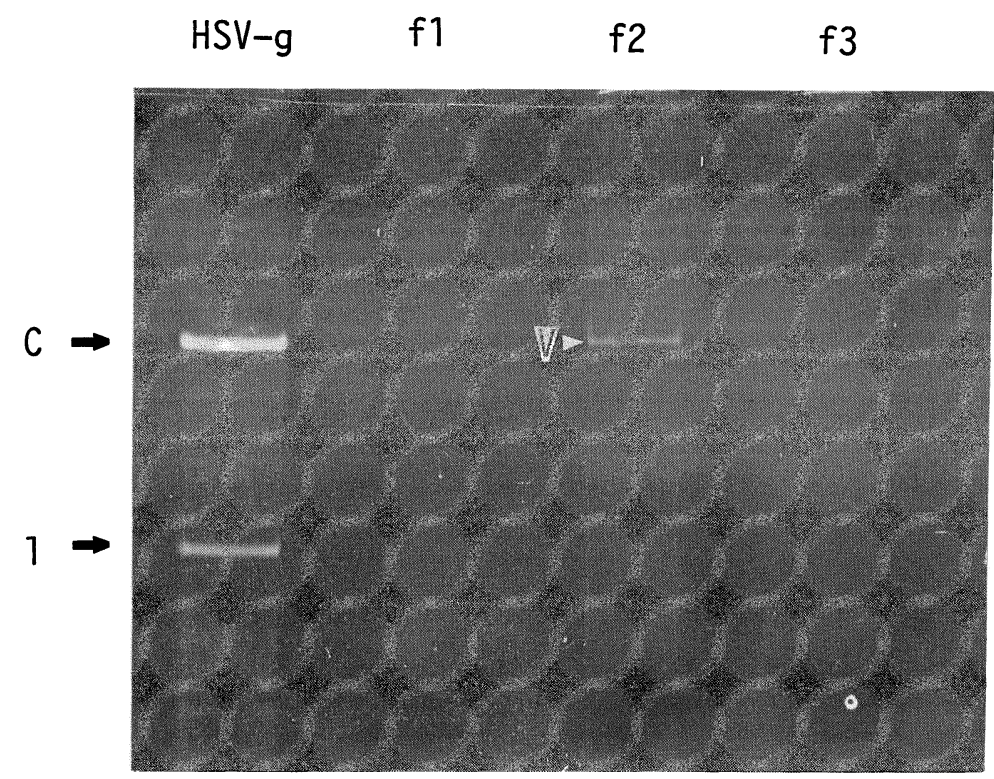

Fig. 2. Electrophoresis of extracts from f1-f3 of lane (PDD) in Fig. 1 on $5 \%$ PAGE under $8 \mathrm{M}$ urea fully denaturing condition. Lane (HSV-g); Purified HSV-g RNA a size marker. Arrows (c) and (1) indicate circular and linear molecules of HSV-g, respectively. Lane (f1) ; RNA eluted from f1. Lane (f2) ; RNA eluted from f2. Arrow (v) indicates the PDD-specific RNA. Lane (f3); RNA eluted from $\mathrm{f} 3$ of lane (PDD) in Fig. 2.

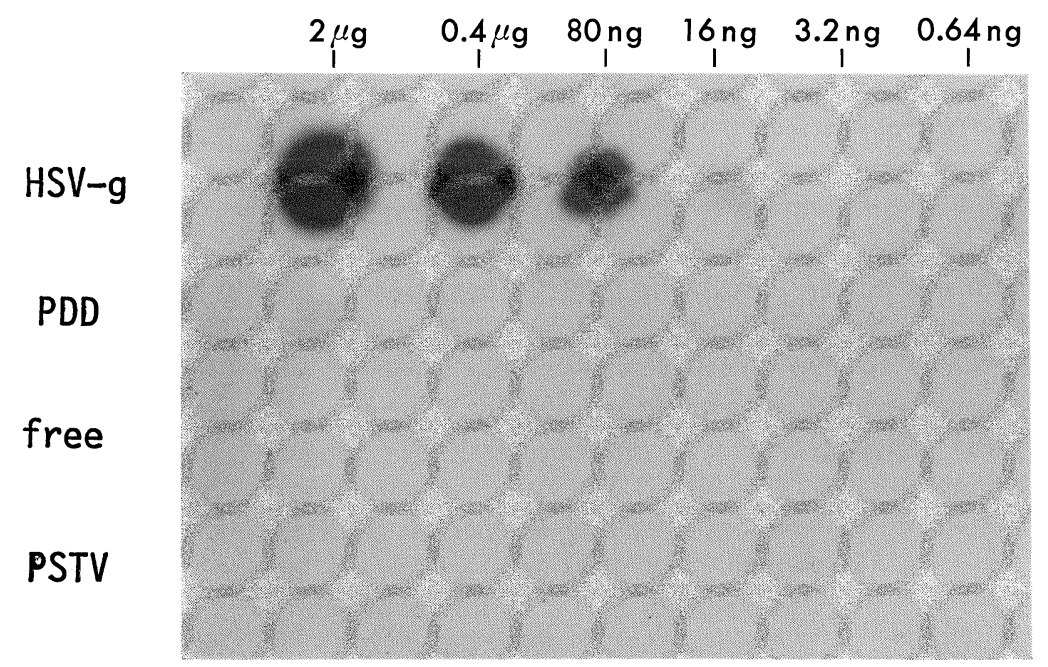

Fig. 3. Dot blot hybridization analysis of HSV-g infected cucumber, PDD affected plum, PDD free plum and PSTV infected tomato. Each spot contains $2 \mu \mathrm{g}, 0.4 \mu \mathrm{g}$, $80 \mathrm{ng}, 16 \mathrm{ng}, 3.2 \mathrm{ng}$ and $0.64 \mathrm{ng}$ of low molecular weight RNAs, from left to right, respectively. 
spotted onto a nitrocellulose paper and hybridized with ${ }^{32} \mathrm{P}$-labelled cDNA of HSV-c. As shown in Fig. 3, HSV-g hybridized well with the probe, and the dilution end-point was $3.2 \mathrm{ng}$. On the other hand, PDD affected plum hybridized to a less extent with the probe. The dilution end-point was $0.4 \mu \mathrm{g}$. In the same condition, no hybridization was occurred with PDD free plum and PSTV.

Discussion. It was shown that a low molecular weight RNA with viroidlike nature was associated with plum dapple disease in Japan. The RNA was specific for PDD affected plums and detected from not only dapple fruits but also leaves with no detectable symptoms by $15 \%$ PAGE assay under non-denaturing condition.

The PDD-associated RNA (PDD-RNA) migrated in the same position with HSV-g RNA, which consisted of 297 nucleotides $^{2}$ ) on a $15 \%$ gel under nondenaturing condition and also a $5 \%$ gel under $8 \mathrm{M}$ urea denaturing condition. These results suggest that PDD-RNA is a single stranded circular molecule which is almost identical to HSV-g in size.

Dot blot hybridization analysis indicated that PDD-RNA has some sequence homology with cDNA of HSV-c, and the hybridization rate was hundred times lower than that of HSV-g (95\% sequence homology with HSV-c). On the other hand, cDNA of HSV-c did not react with PSTV (55\% sequence homology with HSV-c) in the same condition.

Although the infectivity of PDD-RNA has not been shown yet, PDD-RNA may be a viroid distantly related to HSV group on the basis of its electrophoretic mobility (single stranded circular molecules of about 300 nucleotides) and relatively high sequence homology $(55-95 \%)$ to the members of HSV group. Further experiments on inoculation to healthy plum trees and on sequence analysis from cDNA of PDD-RNA are now underway.

\section{References}

1) Loening, U. E.: Biochem. J., 102, 251-257 (1967).

2) Sano, T. et al.: Proc. Japan Acad., 60B, 202-205 (1985).

3) Terai, Y.: Ann. Phytopath. Soc. Japan (1985) (abstr) (in press).

4) —-: Kongetsu no Nouyaku, 29(13), 61-63 (1986).

5) Thomas, P. S.: Proc. Natl. Acad. Sci. USA., 77, 5201-5205 (1980).

6) Uyeda, I. et al.: Ann. Phytopath. Soc. Japan, 50, 331-338 (1984). 